\title{
Semiactive Seat Suspension With a Vibration Absorber
}

Segla, Štefan ${ }^{1}$, Martin Orečný ${ }^{1}$, Nataša Trišović ${ }^{2}$

Faculty of Mechanical Engineering, TU of Košice. E-mail: stefan.segla@tuke.sk

Faculty of Mechanical Engineering, Belgrade University

The paper deals with modelling and optimization of dynamic characteristics of a semiactive suspension of the working machine seat with a vibration absorber. The suspension is composed of a spring paralelly ordered with a semiactive damper controled by the sky-hook control algorithm. For the improvement of the dynamic characteritics of the semiactive suspension there is also analysed the effect of a vibration absorber. The dynamic characteritics of the suspensions are optimized by the multiobjective optimization, where besides the component respecting the effect of the effective accleration of the seat also the effect of the effective relative displacement between the seat and fhe floor of the working machine cabin is considered.

Keywords: semiactive seat suspension, sky-hook control, vibration absorber, modelling, optimization

\section{Acknowledgement}

This work was supported by grant project VEGA No. 1/1205/12.

\section{References}

[1] BALLO, IGOR. Comparison of the properties of active and semi-active suspension. Vehicle System Dynamics. 2007, Vol. 45, No. 3, p. 1065-1073. ISSN 0042-3114.

[2] Optimization Toolbox for use with MATLAB. Users guide, Version 2. Natick (USA): The Mathworks Inc., 2004. p. 152. ISBN 0-13-272550-9.

[3] JAVOŘíK, Jakub; MAŇAS, Miroslav. Tvarová optimalizace pryžové manžety. Strojirrenská technologie. 2011, roč. XVI, č. 1, s. 21-27. ISSN 1211-4162.

[4] GUGLIELMINO, Emanuele et al. Semi-active Suspension Control, Improved Vehicle Ride and Road Friendliness. Berlin: Springer, 2008. p. 312. ISBN 978-1-84800-230-2.

[5] HE, YUPING; MCPHEE, JOHN. Multidisciplinary design optimization of mechatronic vehicles with active suspensions. Journal of Sound and Vibration. 2005, Vol. 283, No. 5, p. 217-241. ISSN 0022-460X.

[6] KALKER-KALKMAN, Cornelia M.; SEGLA, Stefan. Optimization and comparison of trailer suspension systems. Engineering Mechanics. 2000, Vol. 7, No. 6, p. 121-134. ISSN 1802-1484.

[7] PETŘíčEK, Jiří. Vibroizolace sedačky řidiče důlniho stroje pomocí dynamického absorbéru kmitů. Diplomová práce. Liberec: FS TU Liberec, 2010. $65 \mathrm{~s}$.

[8] SÁGA, Milan et al. Vybrané metódy analýzy a syntézy mechanických sústav. Žilina: VTS ŽU v Žiline, 2009. 360 s. ISBN 978-80-89276-17-2.

[9] SEGLA, Stefan; REICH, Stefan. Optimization and comparison of passive, active, and semi-active vehicle suspension systems, In Proceedings of the 12th IFToMM World Congress on Mechanism Science. Besancon (France), 15-18 June, 2007. Edit. by J.P. Merlet. Besancon: INRIA, Sophia-Antipolis, 2007, p. 1221-1226. ISBN 972-375220-450-1.

[10] STEIN, Juraj G.; MÚČKA, Peter; GUNSTON, Tom P. A study of locomotive driver's seat vertical suspension system with adjustable damper. Vehicle System Dynamics. 2009, Vol. 47, No. 3, p. 363-386. ISSN 0042-3114.

[11] NAD, Milan. Analysis of modal properties of beam structural elements with reinforcing core. Machine Dynamics Research. 2010, Vol. 34, No. 4, p. 53-61. ISSN 2080-9948.

[12] VENHOVENS, Paul J. Th. Optimal Control of Vehicle Suspensions. Delft: Delft University of Technology, 1993. p. 378. ISBN 90-370-0093-2.

[13] HOLESOVSKY, Frantisek; NAPRSTKOVA, Natasa, NOVAK, Martin. GICS for grinding process optimization. Manufacturing Technology. 2012, Vol. XII, No. 12, pp. 27-30. ISSN 1211-4162.

[14] MÁDL, Jan. Design for Machining. Manufacturing Technology. 2009, Vol. IX, No. 9, pp. 81-85. ISSN 12114162. 